medRxiv preprint doi: https://doi.org/10.1101/2020.10.06.20207597; this version posted October 6, 2020. The copyright holder for this preprint (which was not certified by peer review) is the author/funder, who has granted medRxiv a license to display the preprint in perpetuity.

It is made available under a CC-BY 4.0 International license .

\title{
Consideration for the asymptomatic transmission of COVID-19: Systematic Review and Meta-Analysis
}

\author{
Khaiwal Ravindra ${ }^{1 *}$, Vivek Singh Malik ${ }^{1,2}$, Bijaya K Padhi ${ }^{1}$, Sonu Goel ${ }^{1}$ and Madhu Gupta ${ }^{1}$ \\ ${ }^{1}$ Department of Community Medicine and School of Public Health, Post Graduate Institute of \\ Medical Education and Research, Chandigarh, India - 160012 \\ ${ }^{2}$ Department of Pediatrics, Advanced Pediatric Centre, Post Graduate Institute of Medical \\ Education and Research, Chandigarh, India - 160012
}

\begin{abstract}
:
Objective: Worldwide countries are experiencing viral load in their population, leading to potential infectivity of asymptomatic COVID-19. Current systematic review and meta-analysis aimed to investigate the role of asymptomatic infection worldwide reported in family-cluster, adults, children, health care workers, and travelers.
\end{abstract}

Design: Online literature search (PubMed, Google Scholar, medRixv, and BioRixv) was accomplished using standard Boolean operators, studies published till $07^{\text {th }}$ June 2020.

Setting: Studies were included from case reports, short communication, and retrospective to cover sufficient asymptomatic COVID-19 transmission reported.

Participants: Familial-clusters, adults, children, health care workers, and travelers.

Results: We observed asymptomatic transmission among familial-cluster, adults, children, health care workers, and travelers with a proportion of $32 \% 37 \%, 26 \%, 6 \%$, and $32 \%$, respectively. This study observed an overall proportion of 31\% (95\%CI: 0.19-0.44) with heterogeneity of $\mathrm{I}^{2}(97.28 \%, \mathrm{p}=<0.001)$ among all asymptomatic populations mentioned in this study. Among children and healthcare workers, this study showed no heterogeneity; to overcome the interpretation from a fixed model, the random effect model was also applied to estimate the average distribution across studies included in the meta-analysis.

Conclusion: We found and suggest the rigorous epidemiological history, early isolation, social distancing, and increased quarantine period (at least 28 days) after screening asymptomatic cases as well as their close contacts for chest CT scan even after their negative nucleic acid testing to 
minimize the spread among the community. This systematic review and meta-analysis support asymptomatic COVID-19 transmission between person to person depending on the variation of virus incubation period among individuals. Children especially, school-going aged <18 years, need to be monitored and prevention strategy, e.g., chest CT and social distancing required to prevent the community transmission of COVID-19 in asymptomatic mode.

Keywords: COVID-19, Asymptomatic transmission, CT scan, Age, Children.

*Corresponding author: Prof. Ravindra Khaiwal, E-mail: khaiwal@yahoo.com, Tel.: +911722755262; fax: +911722744401. 
medRxiv preprint doi: https://doi.org/10.1101/2020.10.06.20207597; this version posted October 6, 2020. The copyright holder for this preprint (which was not certified by peer review) is the author/funder, who has granted medRxiv a license to display the preprint in perpetuity.

It is made available under a CC-BY 4.0 International license.

\section{Strengths and limitations of this study}

- Examine the possibility of asymptomatic COVID-19 transmission in the community at different levels.

- Supports contact tracing, social distancing, early isolation, and increased quarantine period to minimize the risk of virus spread.

- Supports chest CT scan and viral nucleic acid testing to identify the asymptomatic cases in the community.

- Supports rigorous epidemiological history with multiple detection methods.

- A higher proportion of asymptomatic incidence was seen, suggests monitoring, and maintaining social distancing. 
Introduction: Symptomatic viral infections have been a significant risk factor for the public. It is more concerned while asymptomatic viral infection occurs in the community. For symptomatic cases, fever, dyspnea, dry cough, and diarrhea are the major sign, and symptoms were reported lasting up to 14 days with a median incubation period 9-12 days. Aerosol transmissions occurred through sneezing or coughing and reported to be the primary route of infection from person to person ${ }^{1}$. Simulation studies have been done and observed asymptomatic transmission among person-person ${ }^{2}$. PCR-based assays were suggested in managing the asymptomatic transmission of the virus by carriers ${ }^{3}$. The first case of asymptomatic transmission of COVID-19 was reported by JAMA on $21^{\text {st }}$ February 2020 by an asymptomatic carrier (He et al., 2020; Wang et al., 2020). Asymptomatic infection was reported as "hidden coronavirus infections" ("infections" or "covert coronavirus infections" 5 . Asymptomatic COVID-19 cases should be quarantined for 14 days, and their nucleic acid test should be negative twice before discharging, which is mentioned in the COVID-19 prevention and control protocol ( $6^{\text {th }}$ edition). Worldwide, interest in asymptomatic COVID-19 infections and their transmission potential has been increased ${ }^{6}$. In China, around $86 \%$ asymptomatic COVID-19 transmission was undocumented before travel restrictions ${ }^{6}$.

Till now, asymptomatic COVID-19 cases have been reported among Familial-cluster ${ }^{7-12}$, pregnant women ${ }^{13,14}$, adults ${ }^{15-24}$, children ${ }^{1,25,26}$, health care worker ${ }^{27-29}$, and travelers ${ }^{30-34}$. Considering the potential transmission of asymptomatic COVID-19 among the community we tried to accumulate the desired information from the general population as well as vulnerable groups from the different backgrounds were taken, and meta-analysis was performed. There are no previous studies available for asymptomatic COVID-19 transmission among different subgroups between person-person.

\section{Methods:}

Search Strategy: For the meta-analysis PRISMA guideline was applied on this study ${ }^{35,36}$, Boolean operators "asymptomatic transmission", "((COVID-19) AND (Coronavirus)) AND (Asymptomatic transmission)", “((COVID-19) OR (Coronavirus)) AND (asymptomatic transmission)", "(SARS-CoV-2) AND (asymptomatic transmission)", "(2019-nCoV) AND (asymptomatic transmission)", "(Wuhan pneumonia) AND (asymptomatic transmission)", “(Wuhan flu) AND (asymptomatic transmission)”, “(2019-nCoV acute respiratory disease) AND 
medRxiv preprint doi: https://doi.org/10.1101/2020.10.06.20207597; this version posted October 6, 2020. The copyright holder for this preprint (which was not certified by peer review) is the author/funder, who has granted medRxiv a license to display the preprint in perpetuity.

It is made available under a CC-BY 4.0 International license .

(asymptomatic transmission)", "(2019-nCoV respiratory syndrome) AND (asymptomatic transmission)" used for the PubMed database, Google scholar, medRxiv, and BioRixv. The study included published literature without language restriction until $07^{\text {th }} \mathrm{June} 2020$. Selection criteria (Inclusion/exclusion criteria): studies with the following conditions were included for the metaanalysis: (1) Case reports, case series, and cohort study, (2) Asymptomatic infection of COVID19 (clinical, laboratory or both confirmed), and (3) Studies reporting cross-sectional were excluded.

Data extraction: Details of authors, sample size, and numbers reported for the asymptomatic infection of COVID-19 were extracted and recorded independently. Data extraction was done separately by two independent reviewers and disagreement was settled by joint discussion. To minimize the risk of duplication of data was carefully handled.

Quality assessment: The Newcastle Ottawa scale (cohort studies) was used to evaluate the selected studies in the current systematic review and meta-analysis ${ }^{35,37}$.

Publication bias: Possible publication bias was not calculated in this study as we have included cohort, case report study design to cover the possible asymptomatic cases considering the current situation causing limited power of the among studies ${ }^{38}$.

Statistical analysis and data synthesis: After extracting the results, studies were pooled, and the effect of asymptomatic transmission of COVID-19 was examined through the random effects method. For continuous outcome standard error (SE) with 95\% CI was calculated. The heterogeneity ( $I^{2}$ statistic) was assessed between studies. $I^{2}$ values the existence of heterogeneity was taken, as suggested by Higgins and colleagues $35,39,40$. Data for meta-analysis was accomplished as described by ${ }^{35,41}$.

\section{Patient and public involvement:}

There was no direct patient or public involvement in this systematic review and meta-analysis.

Results: Literature search: Literature search and screening were done according to the PRISMA chart (Figure: 1). Initially, 4,667 published research articles were identified using online database search. After the removal of 4617 Publications due to duplications, only 50 
medRxiv preprint doi: https://doi.org/10.1101/2020.10.06.20207597; this version posted October 6, 2020. The copyright holder for this preprint (which was not certified by peer review) is the author/funder, who has granted medRxiv a license to display the preprint in perpetuity.

It is made available under a CC-BY 4.0 International license.

research articles were shortlisted, followed by further screened for relevance. Finally, 27 articles meeting the inclusion criteria were grouped into the family-cluster (total studies: 06), Adults (total studies: 10), Children (total studies: 03), health care workers (total studies: 03), and travelers (total studies: 05) were included in the quantitative synthesis of the current study.

Characteristics of the Study: The main components of the studies are summarized (Table 1). All published research articles fall under the cohort (observational) study design. Most of the studies are from China, Korea, USA, Japan, and Germany. The study included articles published/available online till $07^{\text {th }}$ June 2020.

Table 1: Characteristics of the study participants

\begin{tabular}{|c|c|c|c|c|c|}
\hline Author & Country & $\begin{array}{l}\text { Age, years } \\
(\text { mean }( \pm \text { SD }) / \\
\text { median }(\text { IRQ })\end{array}$ & Study Type & $\begin{array}{l}\text { Type of } \\
\text { test }\end{array}$ & Major findings \\
\hline \multicolumn{6}{|c|}{ Family cluster } \\
\hline $\begin{array}{l}\text { Jasper Fuk- } \\
\text { woochan }\end{array}$ & China & $\begin{array}{l}\text { Family: } 36-60 \\
\text { Child: } 10\end{array}$ & Cohort & RT-PCR & $\begin{array}{l}\text { Supports person to person } \\
\text { transmission between family }\end{array}$ \\
\hline Ming Chen & China & $8.5 \pm 0.17$ & Case report & RT-PCR & $\begin{array}{l}\text { The ability of COVID-19 } \\
\text { transmission during the } \\
\text { asymptomatic period even after } \\
\text { negative viral testing }\end{array}$ \\
\hline Shubia Lu & China & 8 & Case report & RT-PCR & $\begin{array}{l}\text { Supports rigorous investigation } \\
\text { in the combination of various } \\
\text { testing methods to for } \\
\text { asymptomatic COVID-19 cases }\end{array}$ \\
\hline GuoaingQian & China & 6 & Brief report & RT-PCR & $\begin{array}{l}\text { Variation in clinical } \\
\text { manifestation across individuals } \\
\text { was observed }\end{array}$ \\
\hline Feng Ye & China & $38 \pm 18.38$ & Cohort & RT-PCR & $\begin{array}{l}\text { Possibility of COVID-19 } \\
\text { transmission by the } \\
\text { asymptomatic carrier during the } \\
\text { incubation period }\end{array}$ \\
\hline Yan Bai & China & 20 & Cohort & RT-PCR & $\begin{array}{l}\text { Support asymptomatic } \\
\text { transmission through a family } \\
\text { contact }\end{array}$ \\
\hline \multicolumn{6}{|l|}{ Adults } \\
\hline SijiaTian & China & 47.5 & Cohort & RT-PCR & $\begin{array}{l}\text { Early isolation and quarantine } \\
\text { for close contacts to prevent } \\
\text { asymptomatic transmission }\end{array}$ \\
\hline G.-u. Kim & Korea & $26(22-47)$ & Research note & RT-PCR & $\begin{array}{l}\text { Supports social distancing to } \\
\text { prevent asymptomatic }\end{array}$ \\
\hline
\end{tabular}


medRxiv preprint doi: https://doi.org/10.1101/2020.10.06.20207597; this version posted October 6, 2020. The copyright holder for this preprint (which was not certified by peer review) is the author/funder, who has granted medRxiv a license to display the preprint in perpetuity.

It is made available under a CC-BY 4.0 International license.

\begin{tabular}{|c|c|c|c|c|c|}
\hline & & & & & transmission \\
\hline $\begin{array}{l}\text { Wei Fang } \\
\text { Kong }\end{array}$ & China & $37.7( \pm 19)$ & Cohort & RT-PCR & $\begin{array}{l}\text { Suggest rigorous } \\
\text { epidemiological history and } \\
\text { chest CT scan as a practical } \\
\text { tools to identify the } \\
\text { asymptomatic COVID-19 cases } \\
\text { in the community }\end{array}$ \\
\hline Guosheng Yin & China & - & Cohort & RT-PCR & $\begin{array}{l}\text { No difference in the } \\
\text { transmission rate of COVID-19 } \\
\text { between asymptomatic and } \\
\text { symptomatic cases }\end{array}$ \\
\hline HengMeng & China & $\begin{array}{l}42.60 \\
( \pm 16.56)\end{array}$ & Cohort & RT-PCR & $\begin{array}{l}\text { Suggest chest CT scan as an } \\
\text { important tool to screen the } \\
\text { asymptomatic COVID-19 cases } \\
\text { in the community }\end{array}$ \\
\hline $\begin{array}{l}\text { Farida Ismail } \\
\text { AI Hosani }\end{array}$ & UAE & $37(30-45)$ & Cohort & RT-PCR & $\begin{array}{l}\text { No transmission among } \\
\text { household contacts after the } \\
\text { implication of strong isolation } \\
\text { policies }\end{array}$ \\
\hline Daihie He & China & - & Cohort & RT-PCR & $\begin{array}{l}\text { Significantly smaller } \\
\text { transmissibility of asymptomatic } \\
\text { cases than symptomatic }\end{array}$ \\
\hline ChengfengQiu & China & $43(8-84)$ & Cohort & RT-PCR & $\begin{array}{l}\text { Transmission occurred after } 14 \\
\text { days quarantine periods, } \\
\text { suggests }\end{array}$ \\
\hline Rui Zhou & China & - & $\begin{array}{l}\text { Short } \\
\text { communication }\end{array}$ & RT-PCR & $\begin{array}{l}\text { Suggest rigorous } \\
\text { epidemiological history and } \\
\text { nucleic acid testing }\end{array}$ \\
\hline $\begin{array}{l}\text { Shin Young } \\
\text { Park }\end{array}$ & Korea & $38(20-0)$ & Report & RT-PCR & $\begin{array}{l}\text { Supports contact tracing, testing } \\
\text { and increasing quarantine to } \\
\text { prevent asymptomatic COVID- } \\
19 \text { transmission in the } \\
\text { community }\end{array}$ \\
\hline \multicolumn{6}{|l|}{ Children } \\
\hline Zhiliang $\mathrm{Hu}$ & China & $<15$ & Cohort & RT-PCR & $\begin{array}{l}\text { Suggest close contact tracing, } \\
\text { and nucleic acid testing to } \\
\text { identify the asymptomatic } \\
\text { COVID-19 tracing the } \\
\text { community }\end{array}$ \\
\hline HaiyanQiu & China & $8.3( \pm 3.5)$ & Cohort & RT-PCR & $\begin{array}{l}\text { Possibility of asymptomatic } \\
\text { COVID-19 transmission by } \\
\text { close contacts }\end{array}$ \\
\hline Xin Tan & China & - & Cohort & RT-PCR & $\begin{array}{l}\text { Possibility of asymptomatic } \\
\text { COVID-19 transmission by } \\
\text { intra familial contact }\end{array}$ \\
\hline
\end{tabular}


medRxiv preprint doi: https://doi.org/10.1101/2020.10.06.20207597; this version posted October 6, 2020. The copyright holder for this preprint (which was not certified by peer review) is the author/funder, who has granted medRxiv a license to display the preprint in perpetuity.

\begin{tabular}{|c|c|c|c|c|c|}
\hline Anne Kimball & USA & - & - & RT-PCR & $\begin{array}{l}\text { Reported rapid transmission } \\
\text { among health care worker }\end{array}$ \\
\hline $\begin{array}{l}\text { Vera } \\
\text { Schoierzeck }\end{array}$ & Germany & 48 & Cohort & RT-PCR & $\begin{array}{l}\text { Suggest nucleic acid testing for } \\
\text { asymptomatic COVID-19 cases }\end{array}$ \\
\hline Jose Lucar & USA & $>18$ & Cohort & RT-PCR & $\begin{array}{l}\text { transmission reported because } \\
\text { of prolonged surgery done on } \\
\text { asymptomatic COVID-19 case }\end{array}$ \\
\hline \multicolumn{6}{|l|}{ Traveler $>18$} \\
\hline $\begin{array}{l}\text { COVID-19 } \\
\text { Team, Korea }\end{array}$ & Korea & $>18$ & Cohort & RT-PCR & $\begin{array}{l}\text { Supports asymptomatic } \\
\text { transmission with minor } \\
\text { symptoms }\end{array}$ \\
\hline $\begin{array}{l}\text { Kenji } \\
\text { Mizumoto }\end{array}$ & Japan & $>18$ & $\begin{array}{l}\text { Rapid } \\
\text { communication }\end{array}$ & RT-PCR & $\begin{array}{l}\text { Support social distancing to } \\
\text { prevent the asymptomatic } \\
\text { transmission }\end{array}$ \\
\hline Ren Wan & China & $>18$ & $\begin{array}{l}\text { Short } \\
\text { communication }\end{array}$ & RT-PCR & $\begin{array}{l}\text { Possibility of asymptomatic } \\
\text { transmission after } 14 \text { days } \\
\text { quarantine from asymptomatic } \\
\text { COVID-19 case }\end{array}$ \\
\hline Justin WONG & Brunei & - & $\begin{array}{l}\text { Rapid } \\
\text { communication }\end{array}$ & RT-PCR & $\begin{array}{l}\text { Support social distancing \& } \\
\text { nucleic acid testing of } \\
\text { asymptomatic COVID-19 case }\end{array}$ \\
\hline $\begin{array}{l}\text { ThiQuynh Mai } \\
\text { Le }\end{array}$ & China & - & Abstract & - & $\begin{array}{l}\text { Support asymptomatic COVID- } \\
19 \text { viral transmissibility in the } \\
\text { absence of signs and symptoms }\end{array}$ \\
\hline
\end{tabular}

Note: -: Missing values (mean/median values were not reported)

Quality assessment: The Newcastle Ottawa Scale (for cohort studies) was used for qualitative evaluation of the studies included in the meta-analysis ${ }^{35,37}$. The risk of bias was assessed based on three domains (selection, comparability, and outcome), as highlighted (Table 2). 
Table 2: Quality assessment: Cohort study quality according to the Newcastle-Ottawa scale

\begin{tabular}{|c|c|c|c|c|c|c|c|c|c|}
\hline \multirow[t]{2}{*}{ Study } & \multicolumn{4}{|c|}{ Selection $* * * * * *$} & \multirow{2}{*}{$\begin{array}{l}\text { Comparability** } \\
5 \\
\end{array}$} & \multicolumn{3}{|c|}{ Outcome $* * * * *$} & \multirow[t]{2}{*}{ Total quality score } \\
\hline & 1 & 2 & 3 & 4 & & 6 & 7 & 8 & \\
\hline \multicolumn{10}{|l|}{ Family cluster } \\
\hline Jasper Fuk-woochan & $*$ & $\mathbf{0}$ & $*$ & $\mathbf{0}$ & $*$ & $*$ & $\mathbf{0}$ & $\mathbf{0}$ & 4 \\
\hline Ming Chen & $*$ & $\mathbf{0}$ & $*$ & $\mathbf{0}$ & $\mathbf{0}$ & $*$ & $\mathbf{0}$ & $\mathbf{0}$ & 3 \\
\hline Shubia Lu & $*$ & $\mathbf{0}$ & $*$ & $\mathbf{0}$ & $\mathbf{0}$ & $*$ & $\mathbf{0}$ & $\mathbf{0}$ & 3 \\
\hline GuoaingQian & $*$ & $\mathbf{0}$ & $*$ & $\mathbf{0}$ & $\mathbf{0}$ & $*$ & $\mathbf{0}$ & $\mathbf{0}$ & 3 \\
\hline Feng Ye & $*$ & $\mathbf{0}$ & $*$ & $\mathbf{0}$ & $\mathbf{0}$ & $*$ & $\mathbf{0}$ & $\mathbf{0}$ & 3 \\
\hline Yan Bai & $*$ & $\mathbf{0}$ & $*$ & $\mathbf{0}$ & $\mathbf{0}$ & $*$ & $\mathbf{0}$ & $\mathbf{0}$ & 3 \\
\hline \multicolumn{10}{|l|}{ Adults } \\
\hline SijiaTian & $*$ & $\mathbf{0}$ & $*$ & $\mathbf{0}$ & $\mathbf{0}$ & $*$ & $\mathbf{0}$ & $\mathbf{0}$ & 3 \\
\hline G.-u. Kim & $*$ & $\mathbf{0}$ & $*$ & $\mathbf{0}$ & $\mathbf{0}$ & $*$ & $\mathbf{0}$ & $\mathbf{0}$ & 3 \\
\hline Wei Fang Kong & $*$ & $\mathbf{0}$ & $*$ & $\mathbf{0}$ & $\mathbf{0}$ & $*$ & $\mathbf{0}$ & $\mathbf{0}$ & 3 \\
\hline Guosheng Yin & $*$ & $\mathbf{0}$ & $*$ & $\mathbf{0}$ & $\mathbf{0}$ & $*$ & $\mathbf{0}$ & $\mathbf{0}$ & 3 \\
\hline HengMeng & $*$ & $\mathbf{0}$ & $*$ & $\mathbf{0}$ & $\mathbf{0}$ & $*$ & $\mathbf{0}$ & $\mathbf{0}$ & 3 \\
\hline Farida Ismail AI Hosani & $*$ & $\mathbf{0}$ & $*$ & $\mathbf{0}$ & $\mathbf{0}$ & $*$ & $\mathbf{0}$ & $\mathbf{0}$ & 3 \\
\hline Daihie $\mathrm{He}$ & $*$ & $\mathbf{0}$ & $*$ & $\mathbf{0}$ & $\mathbf{0}$ & $*$ & $\mathbf{0}$ & $\mathbf{0}$ & 3 \\
\hline ChengfengQiu & $*$ & $\mathbf{0}$ & $*$ & $\mathbf{0}$ & $\mathbf{0}$ & $*$ & $\mathbf{0}$ & $\mathbf{0}$ & 3 \\
\hline Rui Zhou & $*$ & $\mathbf{0}$ & $*$ & $\mathbf{0}$ & $\mathbf{0}$ & $*$ & $\mathbf{0}$ & $\mathbf{0}$ & 3 \\
\hline Shin Young Park & $*$ & $\mathbf{0}$ & $*$ & $\mathbf{0}$ & $\mathbf{0}$ & $*$ & $\mathbf{0}$ & $\mathbf{0}$ & 3 \\
\hline \multicolumn{10}{|l|}{ Children } \\
\hline Zhiliang $\mathrm{Hu}$ & $*$ & $\mathbf{0}$ & $*$ & $\mathbf{0}$ & $\mathbf{0}$ & $*$ & $\mathbf{0}$ & $\mathbf{0}$ & 3 \\
\hline HaiyanQiu & $*$ & $\mathbf{0}$ & $*$ & $\mathbf{0}$ & $\mathbf{0}$ & $*$ & $\mathbf{0}$ & $\mathbf{0}$ & 3 \\
\hline Xin Tan & $*$ & $\mathbf{0}$ & $*$ & $\mathbf{0}$ & $\mathbf{0}$ & $*$ & $\mathbf{0}$ & $\mathbf{0}$ & 3 \\
\hline \multicolumn{10}{|l|}{ Health Care Workers } \\
\hline Anne Kimball & $*$ & $\mathbf{0}$ & $*$ & $\mathbf{0}$ & $\mathbf{0}$ & $*$ & $\mathbf{0}$ & $\mathbf{0}$ & 3 \\
\hline Vera Schoierzeck & $*$ & $\mathbf{0}$ & $*$ & $\mathbf{0}$ & $\mathbf{0}$ & $*$ & $\mathbf{0}$ & $\mathbf{0}$ & 3 \\
\hline Jose Lucar & $*$ & $\mathbf{0}$ & $*$ & $\mathbf{0}$ & $\mathbf{0}$ & $*$ & $\mathbf{0}$ & $\mathbf{0}$ & 3 \\
\hline \multicolumn{10}{|l|}{ Traveler } \\
\hline COVID-19 Team, Korea & $*$ & $\mathbf{0}$ & $*$ & $\mathbf{0}$ & $\mathbf{0}$ & $*$ & $\mathbf{0}$ & $\mathbf{0}$ & 3 \\
\hline Kenji Mizumoto & $*$ & $\mathbf{0}$ & $*$ & $\mathbf{0}$ & $*$ & $*$ & $\mathbf{0}$ & $\mathbf{0}$ & 4 \\
\hline Ren Wan & $*$ & $\mathbf{0}$ & $*$ & $\mathbf{0}$ & $\mathbf{0}$ & $*$ & $\mathbf{0}$ & $\mathbf{0}$ & 3 \\
\hline Justin WONG & $*$ & $\mathbf{0}$ & $*$ & $\mathbf{0}$ & $\mathbf{0}$ & $*$ & $\mathbf{0}$ & $\mathbf{0}$ & 3 \\
\hline ThiQuynh Mai Le & $*$ & $\mathbf{0}$ & $*$ & $\mathbf{0}$ & $\mathbf{0}$ & $*$ & $\mathbf{0}$ & $\mathbf{0}$ & 3 \\
\hline
\end{tabular}

Note: Selection; 1) Representativeness of the exposed cohort, 2) Selection of the non-exposed cohort, 3) Ascertain exposure, 4) Demonstration that outcome of interest was not present at the start of study; Comparability; 5) Comparability of cohorts based on the design or analysis controlled for confounders; Outcome: 6) Assessment of outcome, 7) Was follow-up long enough for outcomes to occur, 8) Adequacy of follow-up of cohorts. 
medRxiv preprint doi: https://doi.org/10.1101/2020.10.06.20207597; this version posted October 6, 2020. The copyright holder for this preprint (which was not certified by peer review) is the author/funder, who has granted medRxiv a license to display the preprint in perpetuity.

It is made available under a CC-BY 4.0 International license .

Publication bias: This study included studies published as well as unpublished literature on MedRxic and BioRiv, as long as it meets study inclusion criteria.

Meta-analysis: The outcomes of the current meta-analysis (Table 3) and forest plot of asymptomatic positivity of COVID-19 among population (Figure 2) and different sub-groups (Figure 3) are shown. A random-effects model was used for the reported asymptomatic COVID19 transmission at different levels in the community. Current meta-analysis observed heterogeneity among familial-clusters with $\mathrm{I}^{2}=46.02 \%, p=0.0 .10$ with proportion of $32 \%\left(95 \% \mathrm{CI}=(0.09-0.59)\right.$, adults (aged $>18$ years) $\mathrm{I}^{2}=98.44 \%, \mathrm{p}=<0.001$ with proportion of $37 \%$ (95\%CI: $0.19-0.57)$, Travelers $\mathrm{I}^{2}=98.18 \%, p=<0.001$ with proportion of $32 \%(95 \% \mathrm{CI}=0.06-$ $0.65)$, this study did not observed any heterogeneity among children and health care workers but the proportion of asymptomatic transmission was seen with rate of $26 \%$ (95\%CI: 0.16-0.37) and $6 \%(95 \%$ CI: $0.00-0.31)$ respectively with overall heterogeneity of $\mathrm{I}^{2}=97.28 \%, \mathrm{p}=<0.001$. We didn't observe any significant difference of heterogeneity between groups $(\mathrm{p}=0.538)$. With no heterogeneity among children and health care workers random effect model observed an overall proportion of $26 \%$ and $6 \%$, respectively. The likelihood ratio (LR) test was applied for random effect vs. fixed effect model to check the weighted difference (Figure 4). This study observed a proportion of $25 \%$ (95\%CI: $0.17-0.35)$, chi-square value 129.9, $\mathrm{p}=<0.0001$ of asymptomatic positivity of COVID-19 among the population.

Table 3: The meta-analysis of asymptomatic transmission for COVID-19 among different sub-groups of the population:

\begin{tabular}{|l|l|l|l|l|l|}
\hline $\begin{array}{c}\text { Risk factor } \\
\text { (Asymptomatic) Group }\end{array}$ & Studies & $\begin{array}{l}\text { Asymptomatic } \\
\text { Population (n) }\end{array}$ & $\begin{array}{l}\text { Total } \\
\text { Sample } \\
\text { Size (N) }\end{array}$ & $\begin{array}{l}\text { Proportion } \\
(\mathbf{9 5 \%} \text { CI) }\end{array}$ & $\boldsymbol{I}^{2}$ \\
\hline Family Cluster & 6 & 9 & 31 & $0.32(0.09-0.59)$ & $46.02 \%, \mathrm{p}=0.10$ \\
\hline Adults (>18 years age) & 10 & 374 & 1688 & $0.37(0.19-0.57)$ & $98.44 \%, \mathrm{p}=<0.001$ \\
\hline Children (<18 years age) & 3 & 36 & 73 & $0.26(0.16-0.37)$ & - \\
\hline Health Care Workers & 3 & 13 & 125 & $0.06(0.00-0.31)$ & - \\
\hline Travelers & 5 & 368 & 876 & $0.32(0.06-0.65)$ & $98.18 \%, \mathrm{p}=<0.001$ \\
\hline Combined (groups) & 27 & 813 & 2793 & $0.31(0.19-0.44)$ & $97.28 \%,<0.001$ \\
\hline
\end{tabular}


Discussion: The current study summarized available retrospective studies, case reports from family-cluster, adults, children, health care workers, and travelers. Person to person asymptomatic transmission was observed among familial-cluster in an asymptomatic COVID-19 child aged ten years showed abnormal chest CT and another child with mild chest CT manifestation when his family members were diagnosed COVID-19 positive showing sign of fever and respiratory issues ${ }^{8,9}$. The study suggests that thorough epidemiological investigations in combination with multiple detection methods (e.g., RT-PCR, chest CT, Rapid IgM-IgG, and serum CRP level) can identify the asymptomatic carriers ${ }^{10,11}$ in the community among varying clinical manifestations between individuals. Another study supports the possibility of asymptomatic transmission among familial-cluster during the incubation period ${ }^{12}$. In a familialcluster of 5 positive COVID-19 patients had contact with other asymptomatic family members who returned from the Wuhan, suggestive of asymptomatic transmission ${ }^{7}$.

Studies included in the current meta-analysis were checked for the likelihood ratio (LR) between random effect and fixed-effect models for the distribution of asymptomatic COVID-19 transmission among the community.

Among pregnant woman's fetuses are at high-risk during any disease outbreak, in pregnant woman with asymptomatic COVID-19 viral infection delivered a baby negative for the COVID19 nucleic acid test Suggestive of no vertical transmission among neonates born to COVID-19 infected mothers ${ }^{14,42-49}$. In Wuhan, a lower fatality rate and higher discharge rate were observed than in Beijing. It is crucial to identify and take necessary control measures among adults of asymptomatic cases to prevent transmission ${ }^{21}$. In South Korea, 41 asymptomatic adults were identified and were confirmed by RT-PCR out of 213 cases ${ }^{17}$. Among 100 asymptomatic cases, $60 \%$ developed delayed symptoms, and none of the asymptomatic cases died, suggesting asymptomatic transmission during the incubation period ${ }^{18}$. Another study did not observe any difference in the symptomatic and asymptomatic COVID-19 transmission rates among patients 22. In adults, CT imaging of asymptomatic COVID-19 individuals has advantages in highly suspicious cases with negative nucleic acid testing ${ }^{17}$. In adults, a serological investigation among 31 out of 34 cases with asymptomatic infection did not require oxygen support during hospitalization ${ }^{15}$. Theoretically, the quantified infection transmission rate shows the estimated risk ratio $(\mathrm{RR})$ of infectivity [3.9\%, (95\% CI: $1.5-11.8)]$ of symptomatic against asymptomatic. 
medRxiv preprint doi: https://doi.org/10.1101/2020.10.06.20207597; this version posted October 6, 2020. The copyright holder for this preprint (which was not certified by peer review) is the author/funder, who has granted medRxiv a license to display the preprint in perpetuity.

It is made available under a CC-BY 4.0 International license .

In asymptomatic adults, the transmission was significantly smaller than that of the symptomatic cases ${ }^{16}$. No gender difference among males and females was observed for asymptomatic transmission $^{20}$.

Further longitudinal surveillance via virus nucleic acid testing is warranted to identify and control the viral load among asymptomatic CVOID-19 cases ${ }^{24}$ in adults. In a study, 4 asymptomatic cases were quarantined for 14 days, and none was able to transmit the infections due to managing proper isolation and quarantine of the cases ${ }^{19}$.

Asymptomatic COVID-19 transmission was seen in children ${ }^{26}$. In a study, 24 asymptomatic cases were screened from close contacts of asymptomatic COIVD-19 ${ }^{25}$. Another study supports the multiple site sampling of close contacts should be performed ${ }^{1}$ among children. In a review, it was observed that the adults as compared to children with COVID-19 infection show mild clinical symptoms and radiological manifestations as previously reported for SARS- and the Middle East respiratory syndrome (MERS)- $\mathrm{CoV}^{50}$.

Health care workers in a nursing facility: Rapid transmission of COVID-19 had been reported in 76 residents cases. and $23(30.3 \%)$ had positive test results, and approximately 13 were asymptomatic on the day of testing, suggesting the possibility of asymptomatic transmission of COVID-19 ${ }^{27}$. Establishing effective infection control strategies to prevent the transmission among frontline health care workers and patients from COVID-19 infections should be managed urgently and on priority. In another study, out of 48 participants observed, two asymptomatic cases become positive, suggesting appropriate symptom-based testing strategies are essential to prevent outbreaks of COVID-19 within hospital settings ${ }^{29}$. In the USA, health care workers not wearing respirators were exposed to an asymptomatic CVOID-19 patient without developing clinical illness ${ }^{28}$.

Traveler: In Korea, COVID-19 was transmitted by 16 infected travelers from other countries. The disease was infectious at this stage, which resulted from close contacts of asymptomatic carriers ${ }^{30}$. Most of the infections on board the Diamond Princess Cruise ship highlight the asymptomatic transmission of COVID-19 in confined settings. To further mitigate the transmissibility of COVID-19, it may be advised to minimize the number of gathering in confined settings ${ }^{32}$. A 36-year-old traveler returned from Wuhan was found COVID-19 positive, 
medRxiv preprint doi: https://doi.org/10.1101/2020.10.06.20207597; this version posted October 6, 2020. The copyright holder for this preprint (which was not certified by peer review) is the author/funder, who has granted medRxiv a license to display the preprint in perpetuity.

It is made available under a CC-BY 4.0 International license .

and other health workers who were in close contact with the patients were also tested RT-PCR positive. However, the patient initially had no symptoms ${ }^{33}$. A higher proportion of asymptomatic (12\%) was reported among travelers returning to Brunei. In another study, it was suggested to increase the testing facility for asymptomatic COVID-19 cases ${ }^{34}$. Similarly, an asymptomatic COVID-19 patient showed viral transmissibility without showing any signs and symptoms in travelers from China ${ }^{31}$. Although, we recommend early isolation for and social distancing for asymptomatic COVID-19 cases, which may led to psychological and emotional loss as reported in qualitative study from $\mathrm{UK}^{51}$.

Limitations: There are some limitations in the current systematic review and meta-analysis. A mixed population, a continuous variable, variation in clinical conditions, and statistical methods may differ and cause heterogeneity among studies included in the current meta-analysis. Further, the study included only asymptomatic COVID-19 transmission reported cases that were included.

Study Importance: This is the first study reviewing the possibility of asymptomatic COVID-19 transmission at different levels in the community and identified the potential role of isolation, identification of close contacts, social distancing and testing asymptomatic COVID-19 cases with chest CT scan and nucleic acid testing to minimize the spread of the virus in the community.

The implication of our study: This is the first meta-analysis on the possibility of asymptomatic COVID-19 transmission covering different levels in the community.

Conclusion: Currently, there is no evidence of COVID-19 transmission ability in the asymptomatic stage, but evidence suggests that asymptomatic infections were not limited from neonates to children and adults. In young people, strong immune status was supposed to be protected against the COVID-19 severity. We hypothesize that the asymptomatic carriers, either children or adults, should be vigilant as they are capable of shielding and transmitting the infection in their incubation period without showing any signs and symptoms. As the evidence supports the involvement of lung function in asymptomatic COVID-19 cases, we recommend the chest CT scans among asymptomatic cases, a useful tool to monitor and trace cases in their incubation period. 
medRxiv preprint doi: https://doi.org/10.1101/2020.10.06.20207597; this version posted October 6, 2020. The copyright holder for this preprint (which was not certified by peer review) is the author/funder, who has granted medRxiv a license to display the preprint in perpetuity.

It is made available under a CC-BY 4.0 International license.

Contributors: Dr. Khaiwal Ravindra: Concept design, data extraction, interpretation, final correction and writing first draft. Mr. Vivek Singh Malik: Data extraction, interpretation and writing first draft. Dr. Bijaya K Padhi: Interpretation, internal review of data, review and editing. Dr. Sonu Goel: Discussion, review and editing. Dr. Madhu Gupta: Internal review of data, review and editing.

Acknowledgment: We thank the Department of Community Medicine and School of Public Health,PGIMER, and Indian Council of Medical Research, New Delhi.

Funding/Support: None.

Conflict of Interest: None.

Pateint consent: not required.

Data sharing statement: No addditonal data avialable.

\section{References:}

1. Tan X, Huang J, Zhao F, Zhou Y, Li J-Q, Wang X-Y. [Clinical features of children with SARS-CoV-2 infection: an analysis of 13 cases from Changsha, China]. Zhongguo Dang Dai Er Ke Za Zhi Chin J Contemp Pediatr. 2020;22(4):294-298.

2. Chen T-M, Rui J, Wang Q-P, Zhao Z-Y, Cui J-A, Yin L. A mathematical model for simulating the phase-based transmissibility of a novel coronavirus. Infect Dis Poverty. 2020;9(1):24. doi:10.1186/s40249-020-00640-3

3. Rahimi F, Talebi Bezmin Abadi A. Challenges of managing the asymptomatic carriers of SARS-CoV-2. Travel Med Infect Dis. Published online April 2020:101677. doi:10.1016/j.tmaid.2020.101677

4. He G, Sun W, Fang P, et al. The clinical feature of silent infections of novel coronavirus infection (COVID-19) in Wenzhou. J Med Virol. Published online April 10, 2020. doi:10.1002/jmv.25861

5. Wang Y, Kang H, Liu X, Tong Z. Asymptomatic cases with SARS-CoV-2 infection. J Med Virol. Published online May 22, 2020:jmv.25990. doi:10.1002/jmv.25990

6. Park SW, Cornforth DM, Dushoff J, Weitz JS. The time scale of asymptomatic transmission affects estimates of epidemic potential in the COVID-19 outbreak. Epidemics. 2020;31:100392. doi:10.1016/j.epidem.2020.100392

7. Bai Y, Yao L, Wei T, et al. Presumed Asymptomatic Carrier Transmission of COVID-19. JAMA. 2020;323(14):1406. doi:10.1001/jama.2020.2565 
medRxiv preprint doi: https://doi.org/10.1101/2020.10.06.20207597; this version posted October 6, 2020. The copyright holder for this preprint (which was not certified by peer review) is the author/funder, who has granted medRxiv a license to display the preprint in perpetuity.

It is made available under a CC-BY 4.0 International license.

8. Chan JF-W, Yuan S, Kok K-H, et al. A familial cluster of pneumonia associated with the 2019 novel coronavirus indicating person-to-person transmission: a study of a family cluster. The Lancet. 2020;395(10223):514-523. doi:10.1016/S0140-6736(20)30154-9

9. Chen M, Fan P, Liu Z, et al. A SARS-CoV-2 familial cluster infection reveals asymptomatic transmission to children. J Infect Public Health. 2020;13(6):883-886. doi:10.1016/j.jiph.2020.05.018

10. Lu S, Lin J, Zhang Z, et al. Alert for non-respiratory symptoms of Coronavirus Disease 2019 (COVID-19) patients in epidemic period: A case report of familial cluster with three asymptomatic COVID-19 patients. J Med Virol. Published online March 19, 2020. doi:10.1002/jmv.25776

11. Qian G, Yang N, Ma AHY, et al. COVID-19 Transmission Within a Family Cluster by Presymptomatic Carriers in China. Clin Infect Dis. Published online March 23, 2020:ciaa316. doi:10.1093/cid/ciaa316

12. Ye F, Xu S, Rong Z, et al. Delivery of infection from asymptomatic carriers of COVID-19 in a familial cluster. Int J Infect Dis. 2020;94:133-138. doi:10.1016/j.ijid.2020.03.042

13. Chang L, Yan Y, Wang L. Coronavirus Disease 2019: Coronaviruses and Blood Safety. Transfus Med Rev. 2020;34(2):75-80. doi:10.1016/j.tmrv.2020.02.003

14. Lu D, Sang L, Du S, Li T, Chang Y, Yang X. Asymptomatic COVID-19 infection in late pregnancy indicated no vertical transmission. J Med Virol. Published online April 30, 2020:jmv.25927. doi:10.1002/jmv.25927

15. Al Hosani FI, Kim L, Khudhair A, et al. Serologic Follow-up of Middle East Respiratory Syndrome Coronavirus Cases and Contacts-Abu Dhabi, United Arab Emirates. Clin Infect Dis. 2019;68(3):409-418. doi:10.1093/cid/ciy503

16. He D, Zhao S, Lin Q, et al. The relative transmissibility of asymptomatic COVID-19 infections among close contacts. Int $J$ Infect Dis. 2020;94:145-147. doi:10.1016/j.ijid.2020.04.034

17. Kim G -u., Kim M-J, Ra SH, et al. Clinical characteristics of asymptomatic and symptomatic patients with mild COVID-19. Clin Microbiol Infect. Published online May 2020:S1198743X20302688. doi:10.1016/j.cmi.2020.04.040

18. Kong W, Wang Y, Hu J, Chughtai A, Pu H. Comparison of clinical and epidemiological characteristics of asymptomatic and symptomatic SARS-CoV-2 infection: A multi-center study in Sichuan Province, China. Travel Med Infect Dis. Published online May 2020:101754. doi:10.1016/j.tmaid.2020.101754

19. Park SY, Kim Y-M, Yi S, et al. Coronavirus Disease Outbreak in Call Center, South Korea. Emerg Infect Dis. 2020;26(8). doi:10.3201/eid2608.201274 
medRxiv preprint doi: https://doi.org/10.1101/2020.10.06.20207597; this version posted October 6, 2020. The copyright holder for this preprint (which was not certified by peer review) is the author/funder, who has granted medRxiv a license to display the preprint in perpetuity.

It is made available under a CC-BY 4.0 International license .

20. Qiu C, Deng Z, Xiao Q, et al. Transmission and clinical characteristics of coronavirus disease 2019 in 104 outside-Wuhan patients, China. J Med Virol. Published online May 5, 2020:jmv.25975. doi:10.1002/jmv.25975

21. Tian S, Hu N, Lou J, et al. Characteristics of COVID-19 infection in Beijing. J Infect. 2020;80(4):401-406. doi:10.1016/j.jinf.2020.02.018

22. Yin G, Jin H. Comparison of Transmissibility of Coronavirus Between Symptomatic and Asymptomatic Patients: Reanalysis of the Ningbo COVID-19 Data. JMIR Public Health Surveill. 2020;6(2):e19464. doi:10.2196/19464

23. Yuen K-S, Ye Z-W, Fung S-Y, Chan C-P, Jin D-Y. SARS-CoV-2 and COVID-19: The most important research questions. Cell Biosci. 2020;10(1):40. doi:10.1186/s13578-02000404-4

24. Zhou R, Li F, Chen F, et al. Viral dynamics in asymptomatic patients with COVID-19. Int J Infect Dis. 2020;96:288-290. doi:10.1016/j.ijid.2020.05.030

25. $\mathrm{Hu} \mathrm{Z}$, Song $\mathrm{C}, \mathrm{Xu} \mathrm{C}$, et al. Clinical characteristics of 24 asymptomatic infections with COVID-19 screened among close contacts in Nanjing, China. Sci China Life Sci. 2020;63(5):706-711. doi:10.1007/s11427-020-1661-4

26. Qiu H, Wu J, Hong L, Luo Y, Song Q, Chen D. Clinical and epidemiological features of 36 children with coronavirus disease 2019 (COVID-19) in Zhejiang, China: an observational cohort study. Lancet Infect Dis. 2020;20(6):689-696. doi:10.1016/S1473-3099(20)30198-5

27. Kimball A, Hatfield KM, Arons M, et al. Asymptomatic and Presymptomatic SARS-CoV-2 Infections in Residents of a Long-Term Care Skilled Nursing Facility — King County, Washington, March 2020. MMWR Morb Mortal Wkly Rep. 2020;69(13):377-381. doi:10.15585/mmwr.mm6913e1

28. Lucar J, Navalkele B, Becker BP, Reed CD, Parham J. Healthcare Personnel Exposure to a Patient with Asymptomatic SARS-CoV2 Infection during a Prolonged Surgical Intervention. Am J Infect Control. Published online June 2020:S0196655320303527. doi:10.1016/j.ajic.2020.05.036

29. Schwierzeck V, König JC, Kühn J, et al. First reported nosocomial outbreak of severe acute respiratory syndrome coronavirus 2 (SARS-CoV-2) in a pediatric dialysis unit. Clin Infect Dis. Published online April 27, 2020:ciaa491. doi:10.1093/cid/ciaa491

30. COVID-19 National Emergency Response Center, Epidemiology and Case Management Team, Korea Centers for Disease Control and Prevention. Early Epidemiological and Clinical Characteristics of 28 Cases of Coronavirus Disease in South Korea. Osong Public Health Res Perspect. 2020;11(1):8-14. doi:10.24171/j.phrp.2020.11.1.03

31. $\mathrm{Hu}$ X, Gao J, Luo X, et al. Severe Acute Respiratory Syndrome Coronavirus 2 (SARSCoV-2) Vertical Transmission in Neonates Born to Mothers With Coronavirus Disease 
medRxiv preprint doi: https://doi.org/10.1101/2020.10.06.20207597; this version posted October 6, 2020. The copyright holder for this preprint (which was not certified by peer review) is the author/funder, who has granted medRxiv a license to display the preprint in perpetuity.

It is made available under a CC-BY 4.0 International license .

2019 (COVID-19) Pneumonia. Obstet Gynecol. 2020;Publish Ahead of Print. doi:10.1097/AOG.0000000000003926

32. Mizumoto K, Kagaya K, Zarebski A, Chowell G. Estimating the asymptomatic proportion of coronavirus disease 2019 (COVID-19) cases on board the Diamond Princess cruise ship, Yokohama, Japan, 2020. Eurosurveillance. 2020;25(10). doi:10.2807/15607917.ES.2020.25.10.2000180

33. Wan R, Mao Z-Q, He L-Y, Hu Y-C, Wei-Chen. Evidence from two cases of asymptomatic infection with SARS-CoV-2: Are 14 days of isolation sufficient? Int J Infect Dis. 2020;95:174-175. doi:10.1016/j.ijid.2020.03.041

34. Wong J, Abdul Aziz ABZ, Chaw L, et al. High proportion of asymptomatic and presymptomatic COVID-19 infections in air passengers to Brunei. J Travel Med. Published online May 5, 2020:taaa066. doi:10.1093/jtm/taaa066

35. Malik VS, Ravindra K, Attri SV, Bhadada SK, Singh M. Higher Body Mass Index Is an Important Risk Factor in COVID-19 Patients: A Systematic Review. SSRN Electron J. Published online 2020. doi:10.2139/ssrn.3605087

36. Moher D, Liberati A, Tetzlaff J, Altman DG, The PRISMA Group. Preferred Reporting Items for Systematic Reviews and Meta-Analyses: The PRISMA Statement. PLoS Med. 2009;6(7):e1000097. doi:10.1371/journal.pmed.1000097

37. Nuorti JP, Butler JC, Farley MM, et al. Cigarette Smoking and Invasive Pneumococcal Disease. N Engl J Med. 2000;342(10):681-689. doi:10.1056/NEJM200003093421002

38. Lau J, Ioannidis JPA, Terrin N, Schmid CH, Olkin I. The case of the misleading funnel plot. BMJ. 2006;333(7568):597-600. doi:10.1136/bmj.333.7568.597

39. Krüger K, Mooren F-C, Pilat C. The Immunomodulatory Effects of Physical Activity. Curr Pharm Des. 2016;22(24):3730-3748. doi:10.2174/1381612822666160322145107

40. Lasselin J, Alvarez-Salas E, Grigoleit J-S. Well-being and immune response: a multisystem perspective. Curr Opin Pharmacol. 2016;29:34-41. doi:10.1016/j.coph.2016.05.003

41. Pearson-Stuttard J, Blundell S, Harris T, Cook DG, Critchley J. Diabetes and infection: assessing the association with glycaemic control in population-based studies. Lancet Diabetes Endocrinol. 2016;4(2):148-158. doi:10.1016/S2213-8587(15)00379-4

42. Chen $\mathrm{H}$, Guo J, Wang $\mathrm{C}$, et al. Clinical characteristics and intrauterine vertical transmission potential of COVID-19 infection in nine pregnant women: a retrospective review of medical records. The Lancet. 2020;395(10226):809-815. doi:10.1016/S01406736(20)30360-3

43. Chen S, Huang B, Luo DJ, et al. [Pregnancy with new coronavirus infection: clinical characteristics and placental pathological analysis of three cases]. Zhonghua Bing Li Xue Za Zhi. 2020;49(5):418-423. doi:10.3760/cma.j.cn112151-20200225-00138 
medRxiv preprint doi: https://doi.org/10.1101/2020.10.06.20207597; this version posted October 6, 2020. The copyright holder for this preprint (which was not certified by peer review) is the author/funder, who has granted medRxiv a license to display the preprint in perpetuity.

It is made available under a CC-BY 4.0 International license.

44. Chen Y, Peng H, Wang L, et al. Infants Born to Mothers With a New Coronavirus (COVID-19). Front Pediatr. 2020;8:104. doi:10.3389/fped.2020.00104

45. Dashraath P, Wong JLJ, Lim MXK, et al. Coronavirus disease 2019 (COVID-19) pandemic and pregnancy. Am J Obstet Gynecol. 2020;222(6):521-531. doi:10.1016/j.ajog.2020.03.021

46. Liu Y, Chen H, Tang K, Guo Y. Clinical manifestations and outcome of SARS-CoV-2 infection during pregnancy. J Infect. Published online March 2020:S0163445320301092. doi:10.1016/j.jinf.2020.02.028

47. $\mathrm{Xu} \mathrm{Y,} \mathrm{Li} \mathrm{X,} \mathrm{Zhu} \mathrm{B,} \mathrm{et} \mathrm{al.} \mathrm{Characteristics} \mathrm{of} \mathrm{pediatric} \mathrm{SARS-CoV-2} \mathrm{infection} \mathrm{and} \mathrm{potential}$ evidence for persistent fecal viral shedding. Nat Med. 2020;26(4):502-505. doi:10.1038/s41591-020-0817-4

48. Zhang L, Jiang Y, Wei M, et al. [Analysis of the pregnancy outcomes in pregnant women with COVID-19 in Hubei Province]. Zhonghua Fu Chan Ke Za Zhi. 2020;55(3):166-171. doi:10.3760/cma.j.cn112141-20200218-00111

49. Zhu H, Wang L, Fang C, et al. Clinical analysis of 10 neonates born to mothers with 2019nCoV pneumonia. Transl Pediatr. 2020;9(1):51-60. doi:10.21037/tp.2020.02.06

50. Zimmermann P, Curtis N. COVID-19 in Children, Pregnancy and Neonates: A Review of Epidemiologic and Clinical Features. Pediatr Infect Dis J. 2020;39(6):469-477. doi:10.1097/INF.0000000000002700

51. Williams SN, Armitage CJ, Tampe T, et al. Public perceptions and experiences of social distancing and social isolation during the COVID-19 pandemic: a UK-based focus group study. BMJ Open 2020;10:e039334. doi:10.1136/ bmjopen-2020-039334 
medRxiv preprint doi: https://doi.org/10.1101/2020.10.06.20207597; this version posted October 6, 2020. The copyright holder for this preprint (which was not certified by peer review) is the author/funder, who has granted medRxiv a license to display the preprint in perpetuity.

It is made available under a CC-BY 4.0 International license.

Figure 1: PRISMA Chart

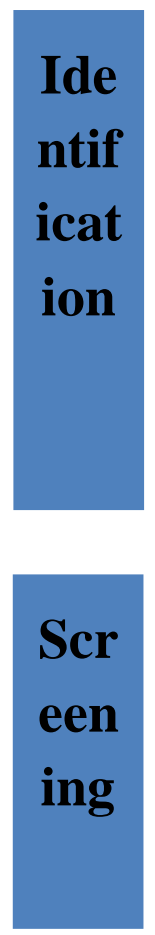

Records identified through database searching (PubMed \& Google scholar $)(\mathrm{n}=1380)$

Additional records identified through others sources (BioRixv, MedRixv, and reference) $(n=3287)$
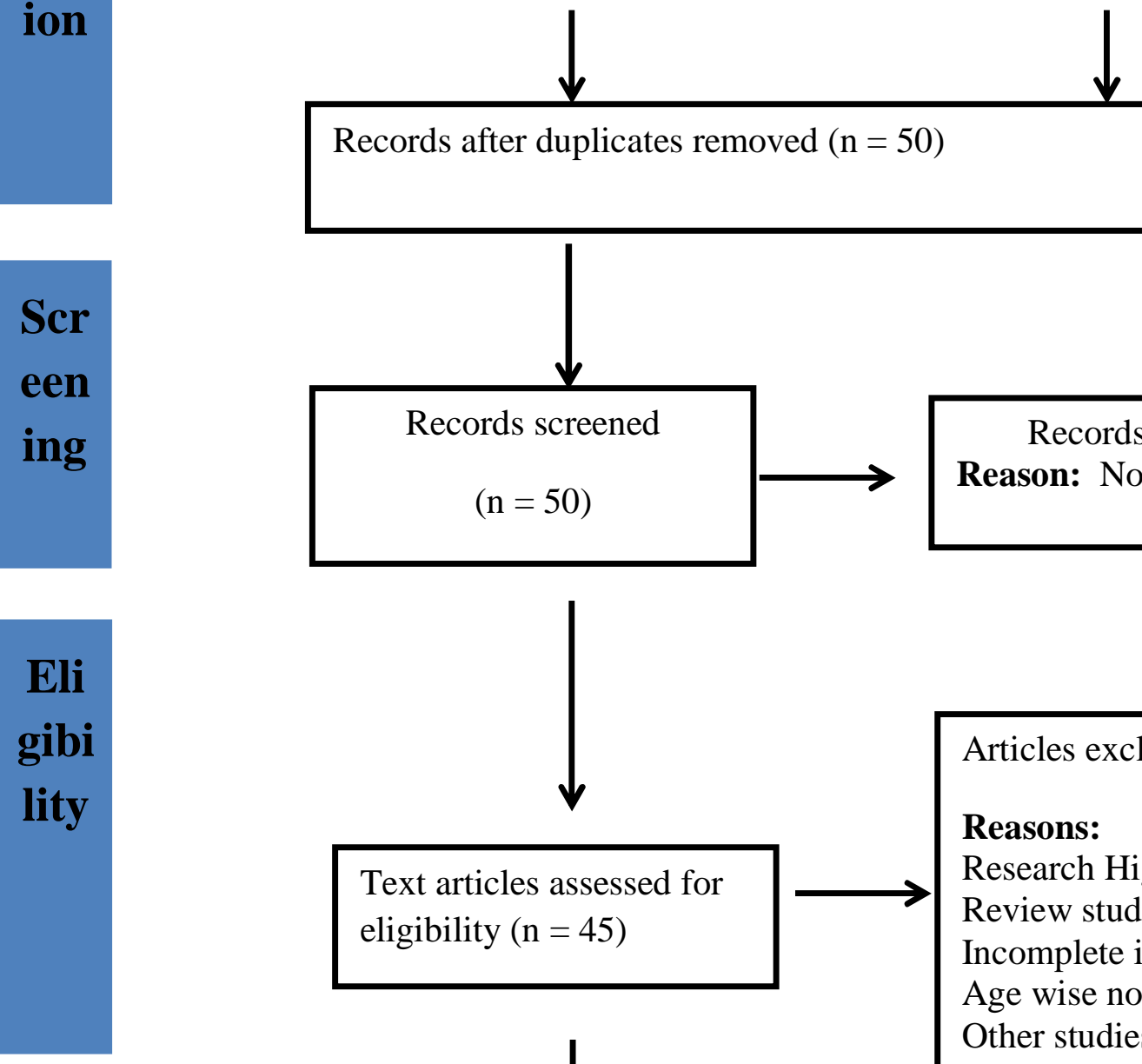

Records after duplicates removed $(n=50)$
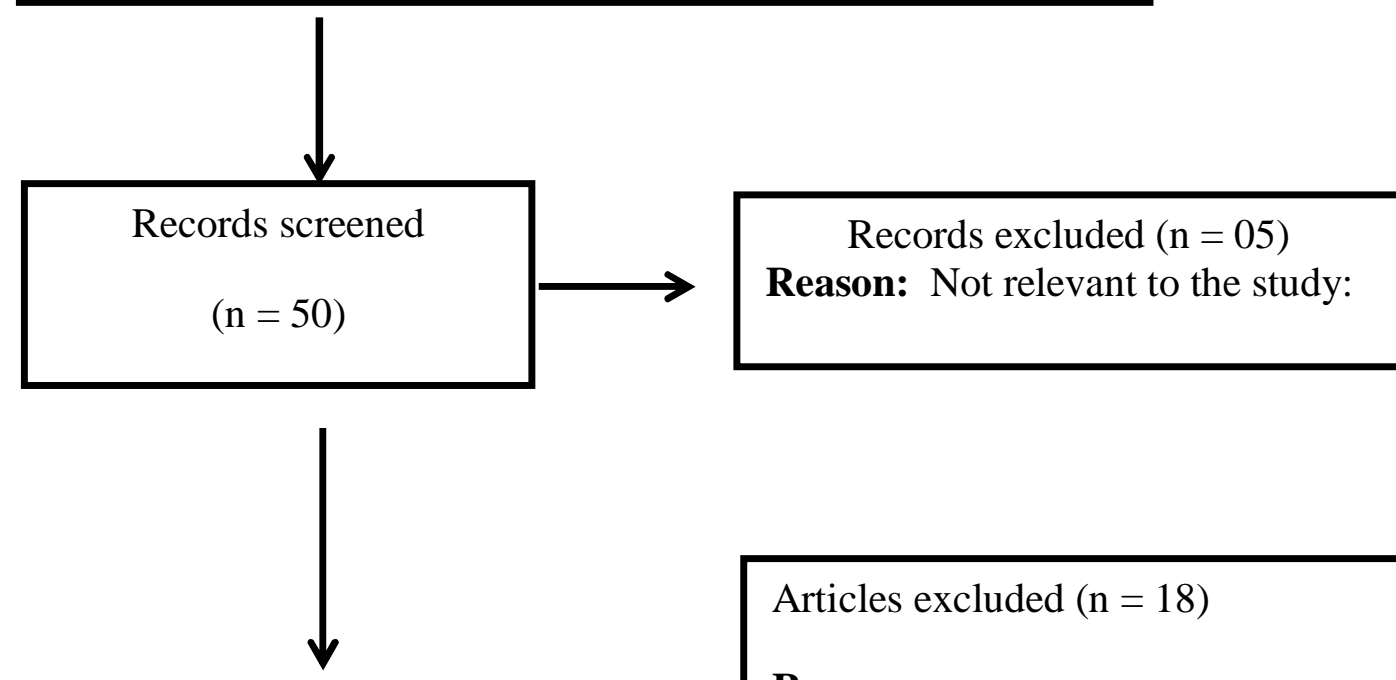

Text articles assessed for eligibility $(n=45)$

Articles excluded $(n=18)$

\section{Reasons:}

Research Highlight: $\mathrm{n}=01$

Review study: $n=07$

Incomplete information: $\mathrm{n}=02$

Age wise no data: 02

Other studies: $\mathrm{n}=06$


\section{Group (Studies):}

Familial-Cluster: $\mathrm{n}=06$

Adults ( $>18$ years): $\mathrm{n}=10$

Children (<18 years): $n=03$

Health Care Workers: $n=03$

Travelers: $\mathrm{n}=05$ 


\begin{tabular}{|c|c|c|c|}
\hline Study & & ES $(95 \% \mathrm{Cl})$ & $\begin{array}{l}\% \\
\text { Weight }\end{array}$ \\
\hline Anne Kimball (2020) & & $0.17(0.09,0.27)$ & 4.16 \\
\hline COVID-19 Team (2020) & & $0.91(0.76,0.98)$ & 3.99 \\
\hline Chengfeng Qiu (2020) & 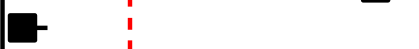 & $0.05(0.02,0.11)$ & 4.20 \\
\hline Daihie He (2020) & 1 & $0.16(0.11,0.22)$ & 4.24 \\
\hline Farida Ismail Al Hosani (2020) & & $0.91(0.76,0.98)$ & 3.99 \\
\hline Feng Ye (2020) & & $0.40(0.05,0.85)$ & 2.90 \\
\hline G.u. Kim (2020) & & $0.19(0.14,0.25)$ & 4.25 \\
\hline Guoaing Qian (2020) & & $0.13(0.00,0.53)$ & 3.27 \\
\hline Guosheng Yin (2020) & & $0.16(0.11,0.22)$ & 4.24 \\
\hline Haiyan Qiu (2020) & & $0.28(0.14,0.45)$ & 4.01 \\
\hline Heng Meng (2020) & & $1.00(0.94,1.00)$ & 4.12 \\
\hline Jasper Fuk-woochan (2020) & & $0.17(0.00,0.64)$ & 3.05 \\
\hline Jose Lucar (2020) & & $1.00(0.03,1.00)$ & 1.55 \\
\hline Justin WONG (2020) & & $0.12(0.07,0.18)$ & 4.22 \\
\hline Kenji Mizumoto (2020) & & $0.51(0.47,0.55)$ & 4.28 \\
\hline Ming chen (2020) & & $0.33(0.01,0.91)$ & 2.44 \\
\hline Ren Wan (2020) & & $0.03(0.00,0.09)$ & 4.16 \\
\hline Rui Zhou (2020) & i & $1.00(0.89,1.00)$ & 3.97 \\
\hline Shin Young Park (2020) & & $0.04(0.01,0.10)$ & 4.19 \\
\hline Shubia Lu (2020) & & $1.00(0.29,1.00)$ & 2.44 \\
\hline Sijia Tian (2020) & & $0.05(0.03,0.08)$ & 4.26 \\
\hline Thi Quynh Mai Le (2020) & & $0.14(0.00,0.58)$ & 3.17 \\
\hline Vera Schoierzeck (2020) & & $0.04(0.01,0.14)$ & 4.08 \\
\hline Wei Fang Kong (2020) & & $0.20(0.16,0.23)$ & 4.28 \\
\hline Xin Tan (2020) & & $0.15(0.02,0.45)$ & 3.59 \\
\hline Yan Bai (2020) & & $0.17(0.00,0.64)$ & 3.05 \\
\hline Zhiliang Hu (2020) & & $0.29(0.13,0.51)$ & 3.88 \\
\hline Overall $\left(I^{\wedge} 2=97.3 \%, p=0.000\right)$ & & $0.31(0.19,0.44)$ & 100.00 \\
\hline
\end{tabular}

Figure 2: Forest plot asymptomatic positivity of COVID-19 among population 
medRxiv preprint doi: https://doi.org/10.1101/2020.10.06.20207597; this version posted October 6, 2020. The copyright holder for this preprint (which was not certified by peer review) is the author/funder, who has granted medRxiv a license to display the preprint in perpetuity.

\section{It is made available under a CC-BY 4.0 International license .}



Figure 3: Forest plot asymptomatic positivity of COVID-19 among different sub-groups 
medRxiv preprint doi: https://doi.org/10.1101/2020.10.06.20207597; this version posted October 6, 2020. The copyright holder for this preprint (which was not certified by peer review) is the author/funder, who has granted medRxiv a license to display the preprint in perpetuity.

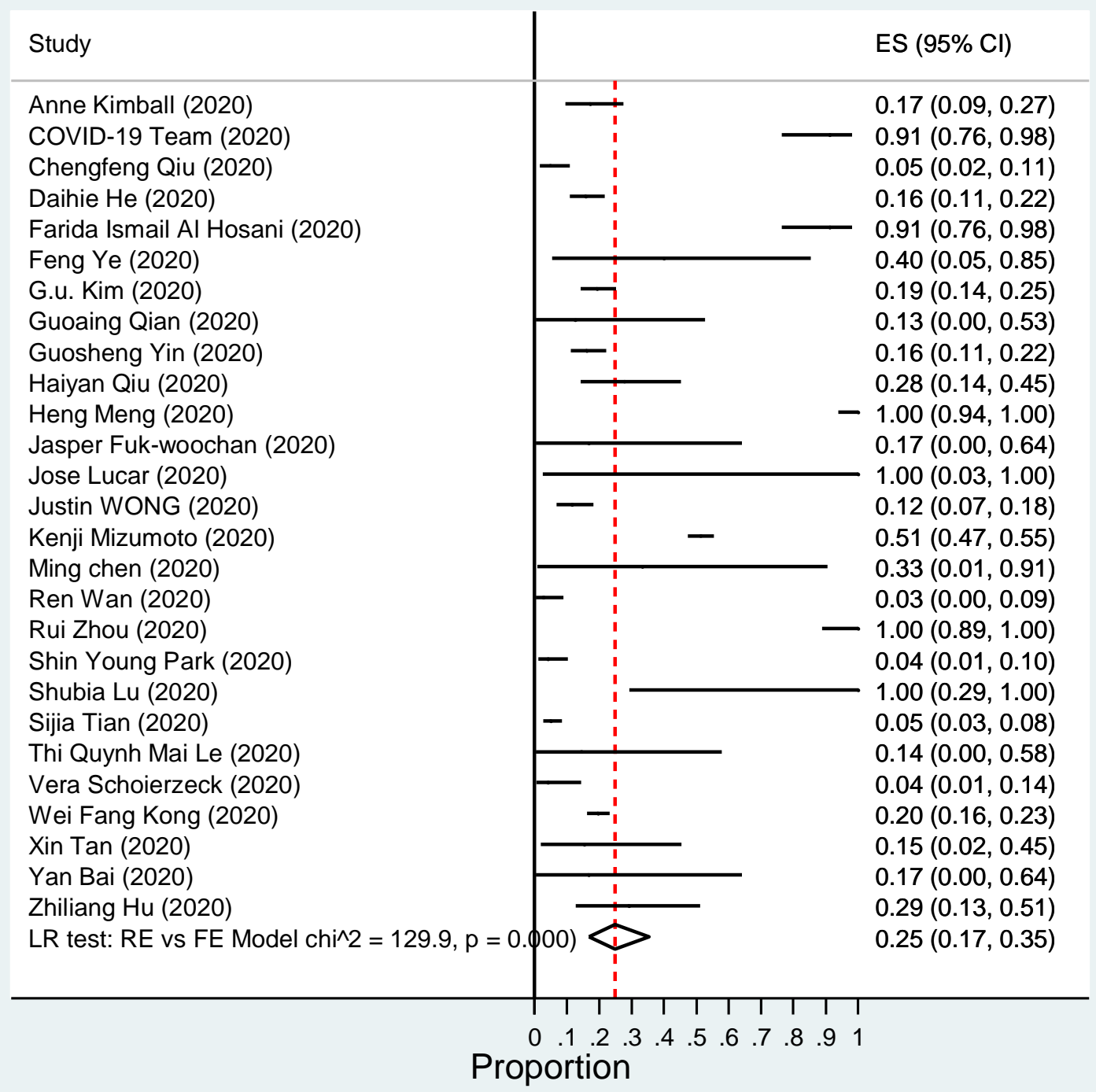

Figure 4: Forest plot: Random Effect and Fixed Effect of Asymptomatic positivity of COVID-19 among population 